\title{
2010年奄美豪雨の汇濫解析と 氾濫発生要因の検討 \\ NUMERICAL ANALYSIS OF INUNDATION FLOW DUE TO HEAVY RAINFALL IN AMAMI OSHIMA ISLAND
}

\author{
橋本彰博1・川井一輝 2 ・田井明3 \\ Akihiro HASHIMOTO, Kazuki KAWAI and Akira TAI \\ 1正会員 博士（工） 九州大学特任助教 大学院工学研究院環境社会部門（广819-0394 福岡市西区元岡 \\ 744) \\ 2非会員＼cjkstart修士（工）＼cjkstart西日本電信電話株式会社（广540-8511 大阪府大阪市中央区馬場町3-15） \\ 3正会員 博士（工） 九州大学助教 高等研究院（干819-0394 福岡市西区元岡744）
}

On October 20, 2010, a heavy rainfall event occurred in Amami region. A record-breaking heavy rainfall amount was observed and it caused overflow in the Sumiyo River. In this study, in order to clarify the characteristics of flood flows in the Sumiyo River Basin where observation data are insufficient, a field survey and numerical analysis were conducted. According to numerical analysis, the direction of inundation flow obtained from hearing investigations and flood level mark recorded in the Nishi-nakama district were reproduced by numerical results. These results suggest that numerical analysis using only rainfall dataset can reproduce inundation processes in the Sumiyo River basin in Amami Osima Island on October 20, 2010. Furthermore, levee failure on the left hand side of the Hiya River accelerated the starting time of the water level rise in the Nishi-Nakama area. In addition, mangrove forests at the river mouth did not affect water level rise in the upper reach of the Sumiyo River.

Key Words : Heavy rainfall, inundation flow analysis, insufficient field data sets, Sumiyo River, Amami Oshima Island

\section{1. はじめに}

近年，気候変動によると考えられる集中豪雨が原因で 引き起こされる災害が毎年発生している. 特に，最近の 水・土砂災害は上流部の比較的狭い流域に多量の雨が短 時間に降ったことが要因となるケースが多く見られる.

こうした流域の河川は主に地方自治体が管理する二級河 川が多いため，災害発生時のデータが十分に整備されて いないことが多い. 災害の発生要因やメカニズムの解明 には，現地調査に加えて詳細な検討ができる数值解析が 適用される $\left.\left.{ }^{1)}, 2\right), 3\right)$. 数值解析を実施するために必要とな るのは，災害時の (1) 河川水位データ，(2)河川流量デー タ，(3) 降雨量データ，(4) 河川横断面データ，（5) 堤内 地の地形データ，(6) 土地利用状況等であるが，二級河 川流域では特に(1)，(2)，(4)に不備が多く，また，(5) と (6) は解析に必要な解像度で整備されているとは限ら ないため, 数值解析の実施が困難となっている.
2010年10月に発生した奄美豪雨災害は，近年気候変動 によって増加が懸念されている異常降雨ならびに高齢者

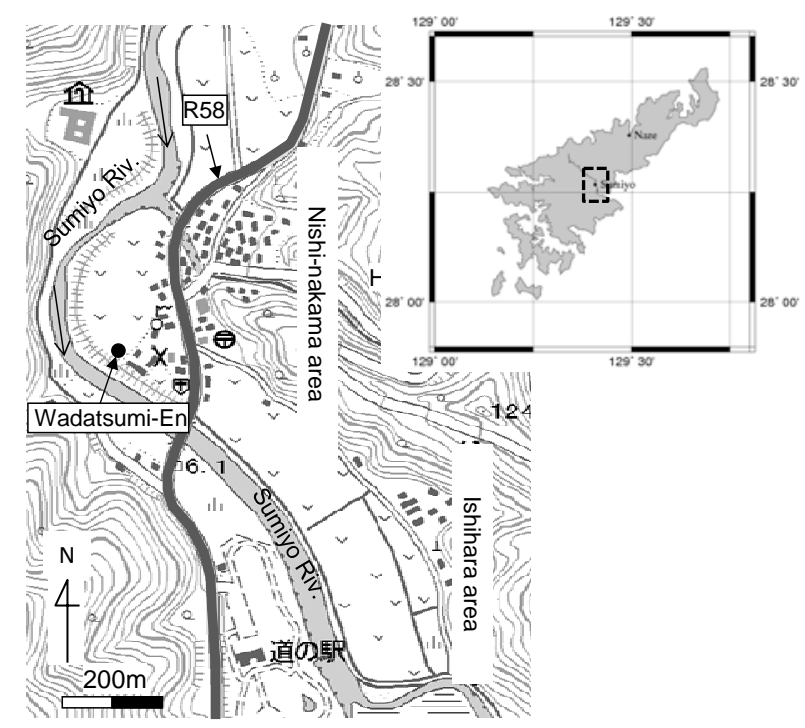

図-1 奄美市住用町（西仲間地区・石原地区） 


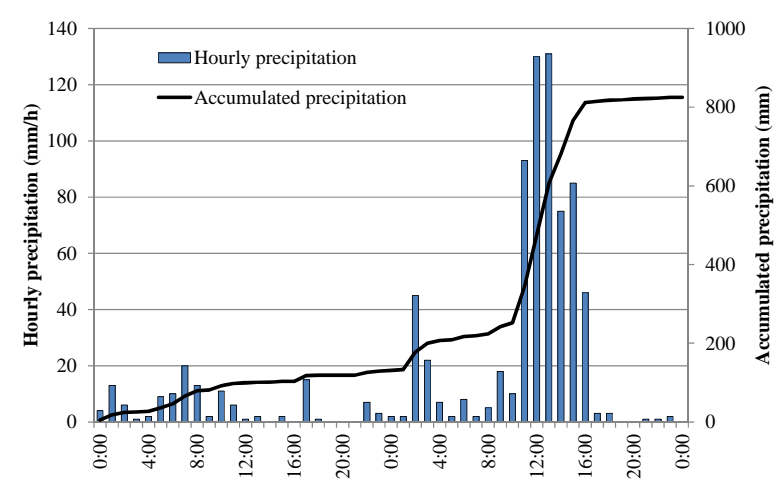

図-2 奄美市住用支所における1時間雨量

など災害弱者が多く居住する地域という，将来の我が国 で発生頻度が増加すると予想される災害の特徵を有して いると考えられる．よって，今回の奄美豪雨災害の特徵 を詳細に調べることは災害適応策を講じる上で極めて重 要である. 本豪雨災害に関しては，現在までに聞き取り 調査により多くの知見が得られている4)，5)。しかしなが ら，二級河川でありかつ離島であることから汇濫解析に 必要なデータが揃っていないため, 定量的な解析は十分 に実施されておらず，詳細な浸水過程などは不明なまま である，そこで本研究では，様々なデータが不足してい る流域として奄美大島の住用川流域（図-1）を取り上げ, 前述の聞き取り調査の結果)を生かすことにより2010年 10月の豪雨による洪水汇濫特性を解明寸ることを目的に 現地調査と数值シミュレーションを実施した.

\section{2. 平成22年10月奄美豪雨による被害状況}

\section{（1）奄美大島地区における被害概要}

2010年10月20日，鹿児島県奄美大島で起きた集中豪雨 は，降り始めからの累積降雨量が島内の4箇所（奄美市 大熊，奄美市住用町，龍郷町長雲，龍郷町大勝）で 800mmを超える記録的な大雨となった．特に住用川流域 の奄美市住用町（図-1）では，130mmを超える1時間降 雨量が11:00から13:00まで2時間継続されるという記録的 な大雨であった（図-2）。その結果，奄美大島にある2 級河川33河川中30河川が汇濫し，死者3名，床上浸水119 棟, 床下浸水767棟という甚大な被害を引き起こした。 死者3名の内，1名は土砂崩れによるもの，残り 2 名は洪 水によるものである，死者はいずれも高齢者で，特に洪 水で死亡した2名はグループホームの入所者であった.

\section{（2）奄美市住用町西仲間地区における浸水過程と特徵}

以下に2名の死者を出した住用川流域の住用町西仲間 地区における浸水状況をまとめる（図-3）.

\section{a）浸水開始時}

まず，冷川の北側において「泥水が山から流れてき た.」「道路が川のようになっていた。」等の証言から，

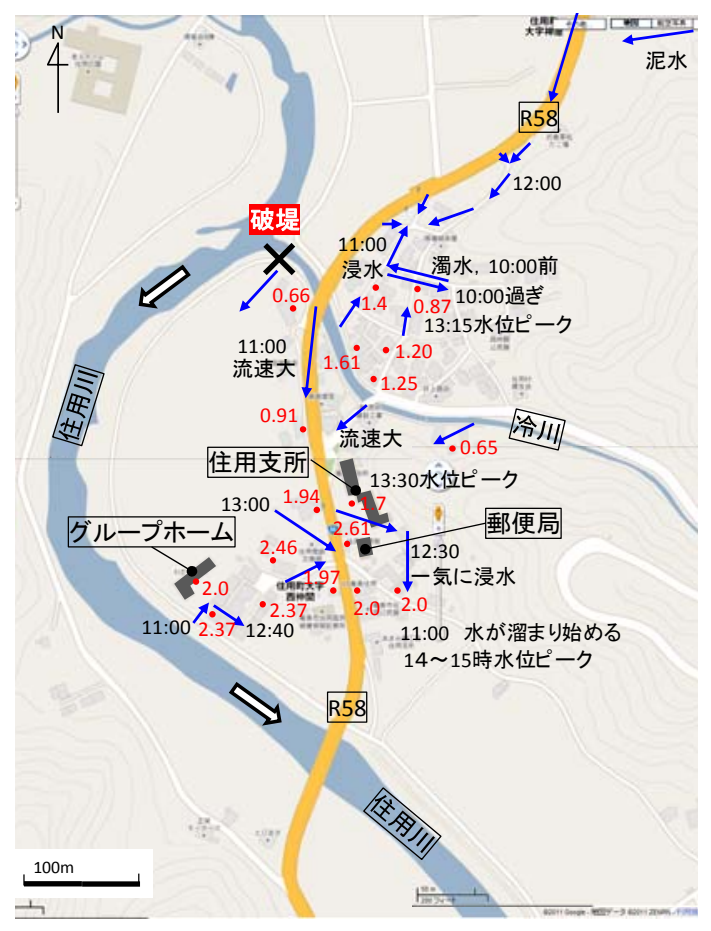

図-3 聞き取り調査で得られた浸水過程（矢印は流 れの向き，赤数字は家屋の浸水深(m)を表す)

猛烈な雨であったため（図-2），土石流となって濁水が 流れ込んだり, 雨水が山地から直接流出して国道58号線 に集まり流下してきたことが分かる。「11:00頃に自宅 前の道路（冷川より北側）に水が流れてきて，11:30に は水位がくるぶし程度の高さとなって，11:40には水位 は腰程度の高さとなって家の中が浸水し始めた。」等の 証言が多数あり，11:00 12:00の時間帯で，冷川より北側 の多くの場所で床上浸水が起こり始めたと考えられる. 一方，冷川の南側では「国道を渡る時，流れがすごく速 くて一人で歩くのは困難だった．」等の証言より，主に 国道から流れ込んできた水によりまず浸水が始まったと 考えられる.

\section{b）水位の急激な上昇}

「12:00頃，建物の犬走りまで水が迫っていた。」， 「12:25頃，一気に床上浸水した」というグループホー 厶職員の証言6)，「弁当を食べているとあっという間に 水が増えた。」という住用支所職員，「12:30頃に室内 の端末を移動させていたら一気に水が入ってきた．」と の郵便局職員の証言，さらに，「12:30頃，水位が腰程 度の高さから一気に水が増えた。」,「12:30頃に一気 に水が押し寄せた．危機感を感じた．」という冷川より 南側にいた人の証言から，12:30前後に冷川の南側で急 激な水位の上昇があったことが分かる。ここで，冷川河 口部（住用川合流部）の左岸側において破堤（破堤幅約 20m）が確認されている. 破堤の時間帯は不明であるが, 上記の状況を考え合わせると12:30よりも前に破堤して 河川水が堤内地に流入し，急激な水位上昇が起きたと考 えられる。 


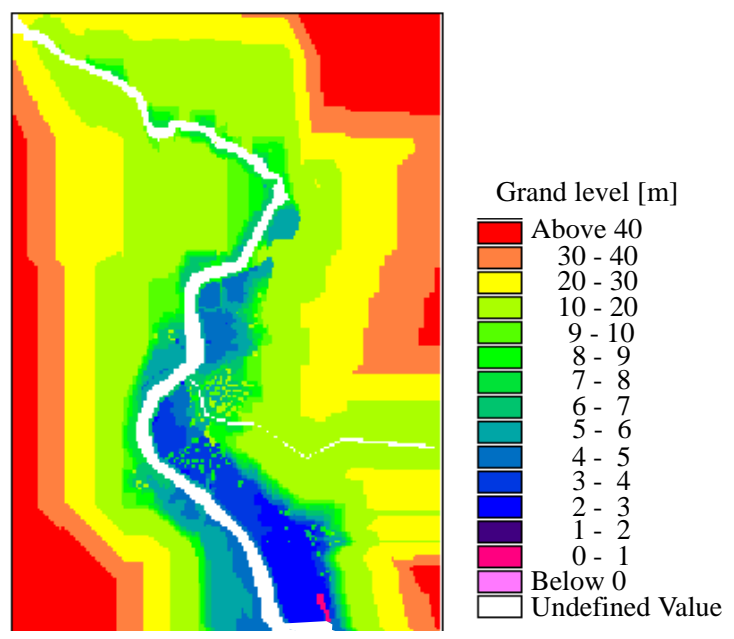

図-4 計算領域の地盤高

\section{3. 解析手法}

対象とした住用川流域には水位計による河川水位の観 測データが一切存在しない，そのため，計算結果の検証 に必要な豪雨当日における住用川の流量および水位は不 明である．また地形データについて，基盤地図情報（国 土地理院）では堤内地の地盤高の特徵（道路（路地）や 荒れ地，畑）が表現出来なかったため，独自に測量を実 施して堤内地の地形データを取得するとともに土地利用 状況を調査した。 そして, 総合支所に設置された雨量計 のデータをもとに流出解析を行って河川上流端の流量を 求め, これを境界条件として一次元不定流解析，平面二 次元汇濫解析を実施し, 住居の浸水痕跡高, 住民からの 聞き取り調査から得られた浸水過程を検証データとして 結果の妥当性を検証した.

\section{（1）現地観測概要}

現地調查は2010年12月23〜24日，2011年1月21～24日， 3月26〜 27日，12月17〜20日，2012年2月6～7日の計5回 実施した. 調查内容は聞き取り調查, 水位計測, 地盤高 の測量および土地利用調查である。調査領域は住用町西 仲間地区および石原地区である。堤内地の地形デー夕は 数值解析の解像度を考慮し, $10 \mathrm{~m}$ 程度の分解能で水準測 量もしくはRTK-GPSを用いた標高の測量を行った。ま た，対象地域においてたんかん畑などの農地や荒地が 所々に数多く存在するため, 農地と荒地の詳細な土地利 用状況を調べた. さらに，家屋に残っていた浸水痕跡高 を一軒ずつ計測した。

\section{（2）数值シミュレーション概要}

流出解析および一次元不定流解析にはMIKE11, 平面 二次元汇濫解析にはMIKE21を使用し, 両者のカップリ ングにMIKEFLOODを用いた.

一次元不定流解析では，鹿児島県により被災後に実施 された河道断面データを使用した，そのため，河床変動

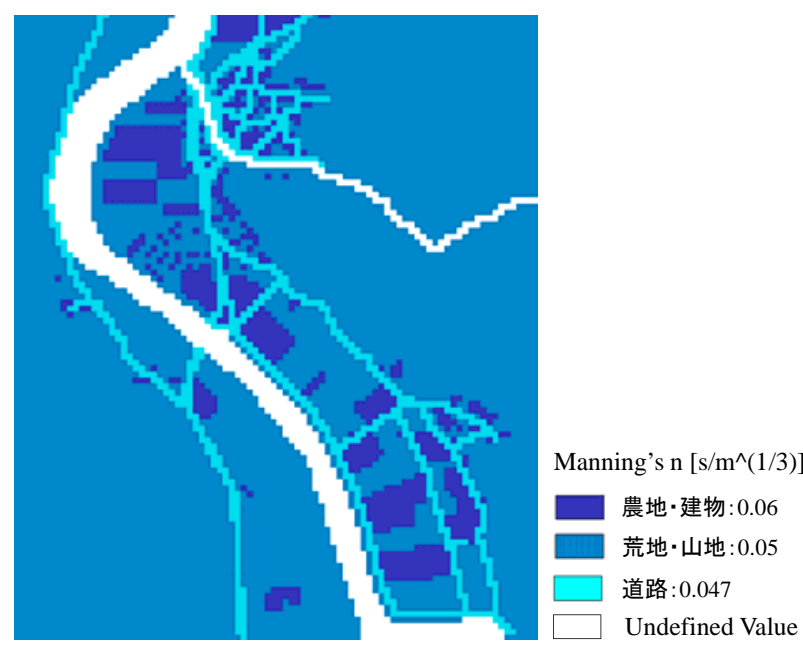

図-5 土地利用と粗度係数 (西仲間地区・石原地区)

の影響は考慮されていない. MIKE11では断面データを 入力寸ることにより水深と径深および断面積の関係が自 動的に計算される. また，支川も同時に解析可能であり， ここでは流入河川として支流の冷川を考慮した。 上流端 の境界条件は住用川では河口から $4.5 \mathrm{~km}$ 地点より上流域 の流出解析から求められた河川流量を，下流端は奄美市 小湊における潮位データをそれぞれ与えた. 冷川も同様 に上流域で流出解析を行って流入流量を求めた.

MIKE11では流出解析として複数のモデルが利用可能だ が，ここでは流域面積が大きくないこと（住用川流域で $\left.48.5 \mathrm{~km}^{2}\right)$ から，単位流量図法を選択した。流出係数は 住用川0.75, 冷川0.85とし, ラグタイムは1時間とした. さらに，住用川下流域にはマングローブ林が群生してお り，これが洪水時に水位上昇を助長したのではないかと の意見もあるため, マングローブ林の影響をマニングの 粗度係数に反映させることで計算に組み込んだ.

平面二次元汇濫解析について, 本研究で対象とした住 用川下流域は比較的小領域であり，市街化されているわ けではなく, 主に農地（たんかん畑）が占める過疎化し た山間地であるため，直交格子を採用した．計算領域は 発電所（35km上流地点）から石原地区までの $1.6 \mathrm{~km} \times$ $3.2 \mathrm{~km}$ の領域とし, 計算格子幅は $10 \mathrm{~m}$ とた. 地盤高の データは現地で実施した測量結果を使用した。.また，建 物について, ここでは単純に周囲よりも地盤高を $4 \mathrm{~m}$ 高 くし，不透過として取り扱った. 粗度係数についても現 地で土地利用状況を確認し, 道路: 0.047 , 農地と建 物 : 0.06 , 山之荒地 : 0.05 とした. 堤外地加堤内地一 の流入は越水と破堤を考慮した。越水による流入は本間 の越流公式を用いて算出した。破堤の取り扱いについて, 既往の研究》により河川からの越水を考慮しない場合, グループホームにおいて浸水深が $0.5 \mathrm{~m} に$ 達するのは破堤 後約20分，郵便局では約35分後であることが示されてい る. ここでは直接聞き取り調査をした郵便局員の証言か ら破堤時刻を11:55に設定した。破堤に至る過程は不明 のため, 計算では破堤時刻に合わせて破堤箇所のメッ 
シュを隣接する堤内地と同じ地盤高となるように設定し た. 破堤流量は一次元解析により得られた冷川水位から 越流公式により計算された. また，山地から直接流入し た雨水が初期の浸水(11:00頃)の要因と考えられることか ら，計算領域に図-2に示される時間雨量を与えた.

\section{4. 結果と考察}

\section{（1）西仲間地区の地形的特徵}

地盤高測量および土地利用調査の結果をそれぞれ図-4, 図-5に示す．冷川右岸側は東側の山地と国道(標高7m)に 挟まれる形で，標高の低い所に住宅地が存在し，そこに 水が溜まりや寸い地形となっている，一方，総合支所な どの公共施設が存在する冷川左岸側は，全体的に標高が 冷川右岸側よりも低く, 郵便局付近から住用川本川に 沿って南東方向に水が流れる地形である.

\section{（2）一次元解析におけるパラメータの検討}

住用川における最大水位の計算結果と50m毎に測定さ れた水位痕跡高(鹿児島県提供)を併せて図-6に示す。マ ニングの粗度係数を変化させて計算を行った結果, マン グローブ域(河口〜 1.15km)：0.045，1.2～2.4km地点区 間 : 0.03，2.45 3.75km地点区間 : 0.04，3.8 4.5km地点 区間 : 0.035 とした時(各区間の間は線形補間)に最も良好 な結果となった。

\section{（3）2010年10月奄美豪雨の再現計算}

本研究では，家屋が多く存在し，被害が大きかった住 用町西仲間地区の浸水状況について考察を行う。まず, 現地調査から得られた痕跡水深(図-3参照)と計算結果の 最大水深を比較した結果を図-7に示す. 冷川の北側およ び南側において計算により得られた浸水深は痕跡水深と ほぼ一致していることがわかる.

次に, 浸水過程について考察寸る. 汇濫解析により得 られた浸水深のコンターを流速ベクトルと併せて図-8に 示す．まず，1時間降雨量が最大(130mm)であった11:00 〜12:00では, 多量の雨水が山地から直接流れ込み, 冷 川右岸側の水が溜まりやすい住宅地で浸水深が $1 \mathrm{~m}$ とな る箇所が発生し，床上浸水が起こり始める(図-8(a)).

11:30になると泠川の左岸側で越水が生じて河川水が国 道に流れ込み，総合支所付近で大きな流速が発生してい る(図-8 (b))．避難勧告が発令された11:50では，グルー プホーム付近の浸水深は $15 \mathrm{~cm}$ 程度であり，この時点で はまだ冷川左岸側の浸水被害はそれほど大きくなってい ない(図-8(c)). その後，破堤が生じると，冷川・住用川 合流部付近の破堤地点から多量の河川水が一気に流入し 始める一方, 冷川右岸からも越水が始まる(図-8(d)). そ して破堤後わずか30分の間に，郵便局やグループホーム 付近で浸水深が $1.0 \mathrm{~m}$ 以上となり，水位が短時間で急激に

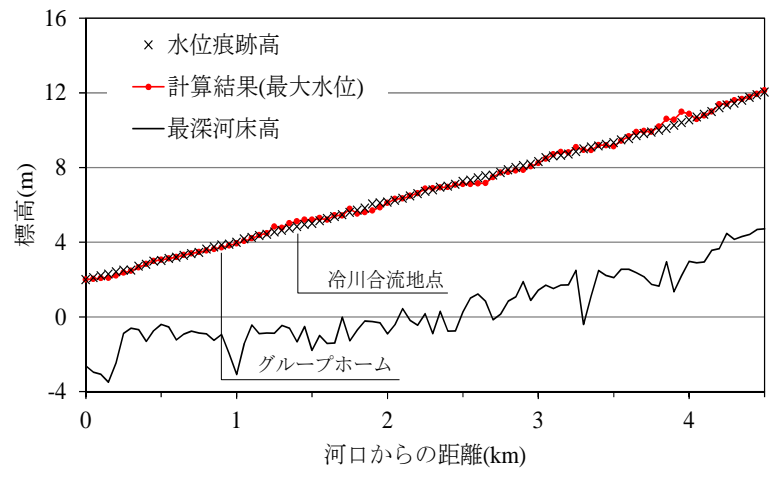

図-6 一次元解析の計算結果（最大水位） と痕跡水 位の比較 $\left(\right.$ 最大流量 $\left.\mathrm{Q}_{\mathrm{P}}=1063 \mathrm{~m}^{3} / \mathrm{s}\right)$

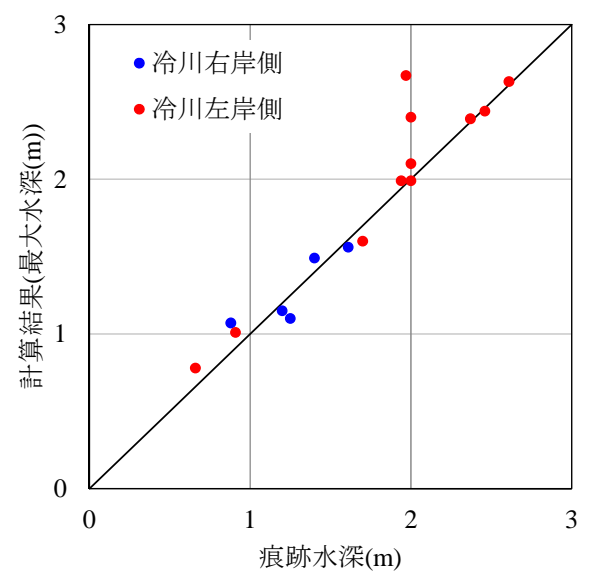

図-7 氾濫解析の計算結果（最大水深） と痕跡水深 の比較

上昇していることがわかる(図-8(e))。13:30頃になると， グループホームや郵便局付近で浸水深が2mを越えてい る(図-8(f)). 以上の結果を上述した聞き取り調査の結果 (図-3) と比較すると, 国道58号線から雨水が直接流入す る現象は再現できていないものの，山の斜面から雨水が 直接流出してくる初期の浸水過程, 住用川および冷川か らの越水と破堤が主要因となってからの水位上昇の時間 帯や浸水方向は聞き取り調査結果を良好に再現している.

\section{5. 洪水氾濫影響要因の検討}

\section{（1）堤内地の急激な水位上昇}

堤内地における急激な水位上昇の要因が破堤によるも のであるか検討するために，破堤が生じない場合の汇濫 解析を行った，その結果を図-9に示す．4．（3）で述心゙ たように，破堤した場合は郵便局やグループホームにお いて破堤から30分の間に急激な水位上昇が起きているが, 破堤を考慮しない場合には同時刻におけるグループホー 么付近での浸水深は $50 \mathrm{~cm}$ 程度であり，この時点ではま だ急激な水位上昇は起きていない(図-9(a)).2名の死者 を出したグループホームにおいて，破堤が生じた場合と 生じていない場合で浸水深の時系列変化を比較した結果 


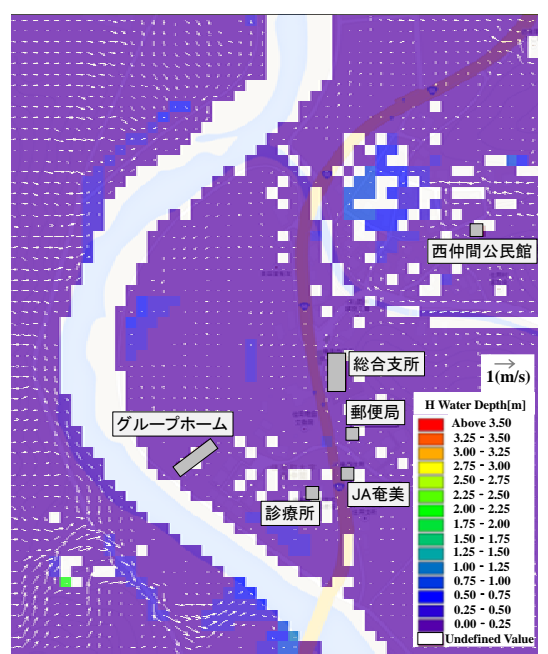

(a) 冷川右岸側で家屋が浸水 (11:00)

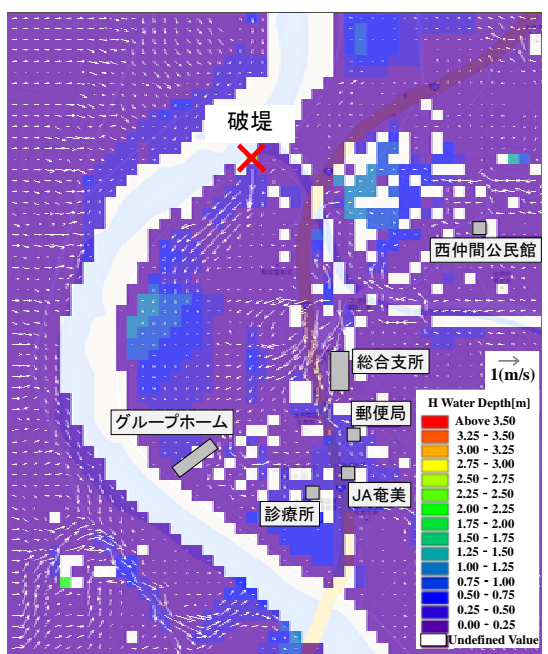

(d) 破堤直後 $(12: 00)$

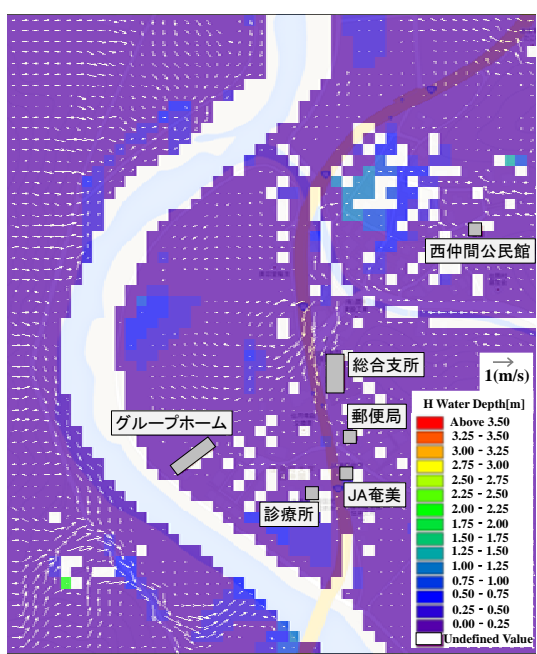

(b) 支所付近の国道58号で大きな 流速 $(11: 30)$

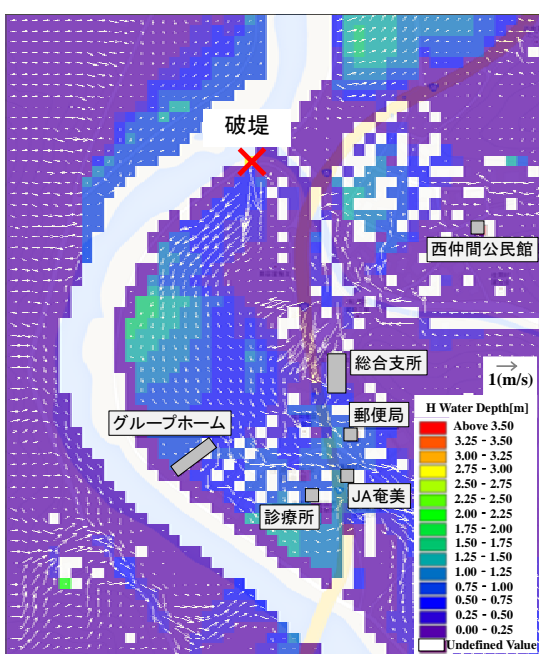

（e）水位が急激に上昇 $(12: 30)$

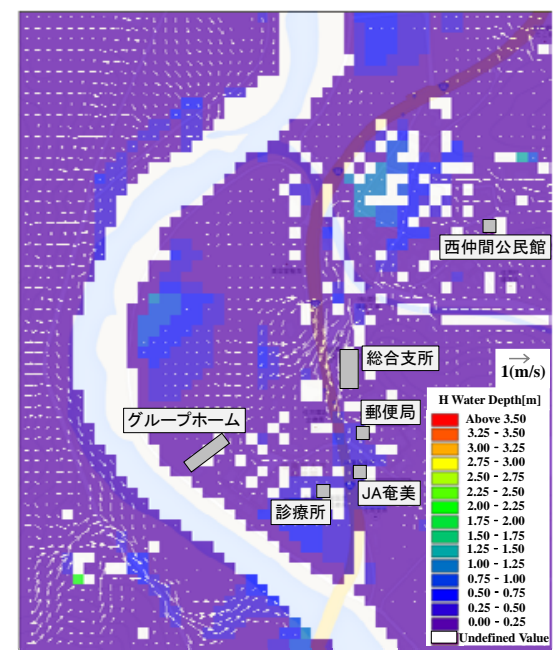

(c) 避難勧告発令時 $(11: 50)$

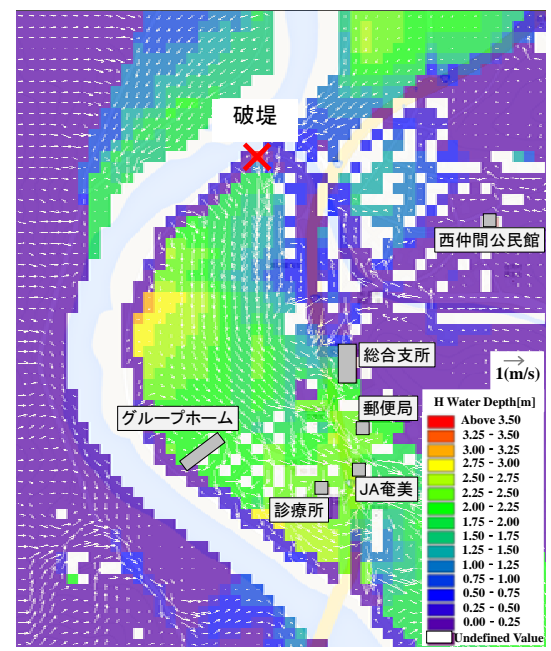

（f）浸水深が2mを越える (13:30)

図-8＼cjkstart汇濫解析による再現計算結果（浸水深をコンター，流速をベクトルで示す．図中のUndefined Valueは水深0 $0 \mathrm{~m}$ を意味する.）

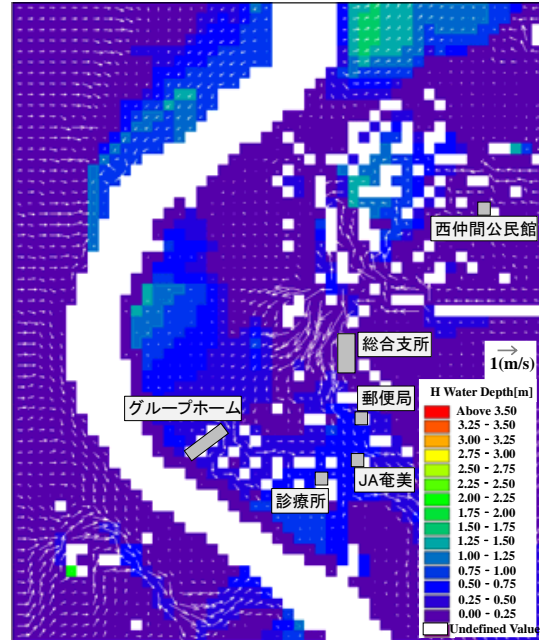

(a) 12:30の浸水状況（図-8 (e) と 同時刻)

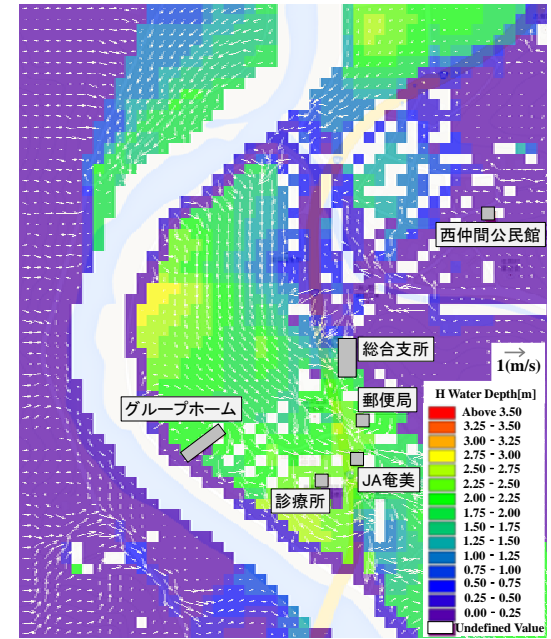

（e）浸水深が2mを越える (13:30)

図-9 破堤が生じない場合の計算結果（浸水深をコンター，流速をベクトルで示寸．図中のUndefined Valueは 水深0mを意味する。） 
を図-10に示す．破堤する場合は破堤後30分（12:30）で 浸水深が1mに達しているのに対して, 破堤が生じない 場合には住用川からの越水が起こる12:50までは大きな 水位上昇は見られない。 しかしながら，その後13:00頃 になると住用川左岸から越水が生じて急激に水位が上昇 し，13:30頃には浸水深が2mを越えて，最大浸水深は破 堤した場合と同様の結果となった(図-9(b)). 以上の結果 から, 最終的な浸水深は同じとなったが, 急激な水位上 昇が始まる時間が破堤によって早まったと推察される.

グループホーム職員の報告吕によると，12:00頃に自主避 難の防災無線を受けて河川の異変を確認していること， ホームからの避難準備を始めたのは12:15頃であること より, 破堤しなければ約30分程度の時間の余裕が生まれ た可能性がある.

\section{（2）マングローブ林の影響}

住用川下流域に群生しているマングローブ林が洪水時 の水位上昇に及ぼした影響を調べた。この計算ではマン グローブ林区間の粗度係数を河道と同じ 0.03 とすること でマングローブ林がない場合を再現した．計算結果を図 -11に示す．この結果より，マングローブ林の影響は下 流側の夕に限られており, 住宅地がある西仲間地区(1.75 〜2.4km区間)ではほとんど影響を及ぼしていないことが わかる. マングローブ林が郡生している区間では河道幅 が非常に広くなるため，抵抗が大きくなってもそれ程水 位上昇には影響を及ぼさないと考えられる。したがって, 今回の水害においてマングローブ林は水位上昇には影響 を及ぼしていなかったと推察される。

\section{6. おわりに}

本研究では, 聞き取り調査の結果を生かすことで, 様々なデータが不足している地域での汇濫特性を解明す ることを目的に現地調査と数值解析を実施した．その結 果, 河床変動, 破堤の取り扱い等, 今後検討すべき点は あるものの, 雨水が山の斜面から直接流出寸る浸水初期 や住用川からの越水と破堤が主要因となってからの浸水 過程など，計算結果は定性的ではあるが聞き取り調查の 結果が再現されており，水位痕跡高も概ね再現されてい た. また，洪水汇濫要因を検討した結果，急激な水位上 昇が破堤により約30分程度早まったこと, マングローブ 林は河川上流側への水位上昇には影響を及ぼさないこと が示唆された。

謝辞 : 本研究は, 平成24年度環境研究総合推進費「S-82（2）亚熱帯化先進地九州における水・土砂災害適応策 の研究」の支援により実施された。ここに記して感謝 の意を表します。

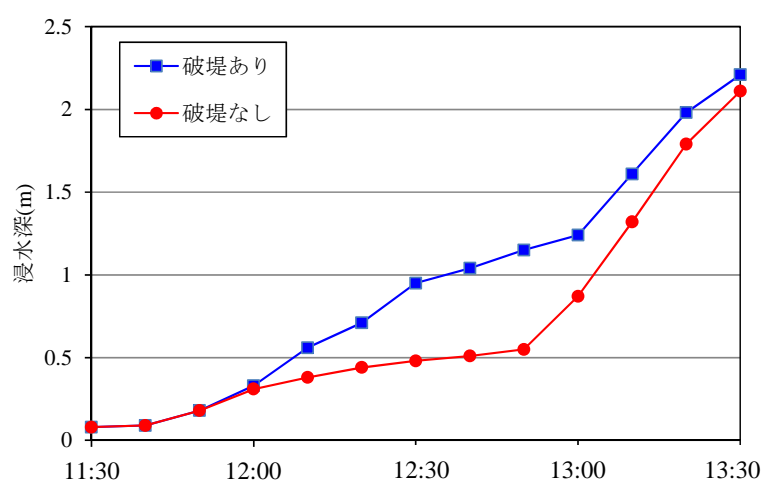

図-10 グループホームにおける浸水深の時間変化 の比較

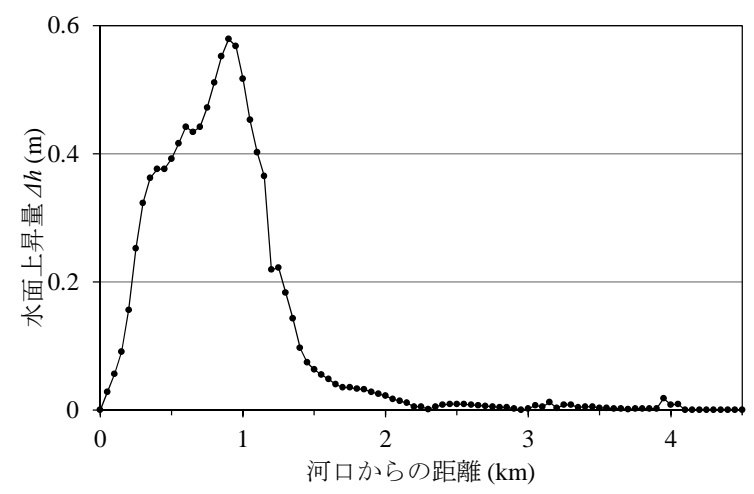

図-11 マングローブ林が水位上昇に及ぼす影響

\section{参考文献}

1) 川池健司，中川一，市川温，丸山寛起 : 平成18年7月豪雨に よる松江市内の都市水害に関する数值解析的検討, 水工学論 文集. 第51巻, pp.535-540, 2007.

2) 秋山壽一郎, 重枝未玲 : 河道・氾濫原包括解析による氾濫流 量の評価と市街地破堤汇濫解析，土木学会論文集B，vol.63， No.3, pp.224-237, 2007.

3) 藤田一郎, 伊藤崇博 : 平成21年 8 月兵庫県佐用町河川災害に おける汇濫解析と避難行動判断基淮に関寸る研究, 河川技術 論文集，vol.17，pp.431-436， 2011.

4) 田井明, 橋本彰博，押川英夫，小松利光 : 2010年10月奄美大 島豪雨時の住用川流域の洪水と住民行動に関する調查，河川 技術論文集，vol.17，pp.437-478，2011.

5) 安永文香, 林博徳, 大槻順朗, 佐藤辰郎, 立道大伸, 島谷幸 宏 : 2010年10月奄美大島豪雨時の汇濫特性と住民行動, 河川 技術論文集，vol.18，pp.511-516， 2012.

6)徳州会グループホームページ： http://www.tokushukai.or.jp/syakai_kouken/calamity/result/domesti c/amami2010/wadatsumi01.html

7) A. Hashimoto, A. Tai, K. Kawai and T. Toshimitsu: Characteristics of Aamami Oshima Island heavy rainfall disaster in October 2010, Proceedings of 2013 IAHR World Congress, A11921 (USB), 2013.

(2014. 9. 30受付) 